\title{
FORMULASI KERUPUK KENTANG GRANOLA (Solanum tuberosum L.) SEBAGAI MAKANAN KULINER KHAS TENGGER JAWA TIMUR
}

\section{Formulation of Potato Crackers Granola (Solanum tuberosum L.) as a Typical Tengger Culinary Food in East Java}

\author{
Claudia Gadizza Perdani, Firda Najmi Amaludin, Susinggih Wijana \\ Jurusan Teknologi Industri Pertanian, FTP Universitas Brawijaya Malang \\ Jl. Veteran, Malang 65145 \\ *Penulis Korespondensi, Email: cgadizza@ub.ac.id
}

\begin{abstract}
ABSTRAK
Kuliner khas memiliki peranan yang penting dalam menarik minat wisatawan baik domestik maupun mancanegara. Potensi komoditas unggulan kawasan Bromo yang baik dikembangkan sebagai kuliner adalah sayuran kentang. Kentang memiliki kandungan pati yang tinggi sehingga berpotensi untuk diolah menjadi kerupuk kentang, dan diharapkan berpotensi menjadi salah satu oleh-oleh khas Tengger. Tujuan dari penelitian ini untuk mengetauhi pengaruh proporsi penambahan tepung tapioka terhadap kualitas fisik kerupuk yang optimal dan mengetauhi tingkat kesukaan kerupuk kentang. Metode penelitian yang digunakan yaitu menggunakan linear programming sebagai penentuan komposisi ke-3 formulasi. Rancangan formulasi kerupuk kentang dibuat dengan menggunakan Rancangan Acak Lengkap (RAL). Berdasarkan penelitian ini kerupuk kentang yang dapat diterima secara organoleptik oleh panelis adalah formulasi ke-3 (kentang 65\%: tapioka 30\%: 5\% bahan tambahan). Hasil analisis kadar air kerupuk kentang sebesar $4.66 \%$, daya patah sebesar $14.90 \mathrm{~N}$ dan daya kembang sebesar $83.2 \%$. Biaya pokok pembuatan kerupuk kentang formulasi ke-3 (tiga) sebesar Rp. 2.819,60 per 100 gram.
\end{abstract}

Kata Kunci: Kentang Varietas Granola, Tepung Tapioka, Kerupuk Kentang

\section{ABSTRACT}

Typical cuisine has an important role in attracting both domestic and foreign tourists. The potential of superior commodities in the Bromo region that are well developed as culinary are potato vegetables. The purpose of this study was to examine the effect of the proportion of tapioca flour addition on the optimal physical quality of crackers and to determine the level of preference for potato crackers. The research method used is using linear programming as the determination of the third composition formulation. The formulation design of potato crackers was made using a Completely Randomized Design (CRD) and each treatment was repeated 3 times. Based on this research, potato crackers that can be received organoleptically by panelists are the 3rd formulation (potato 65\%: tapioca 30\%: 5\% additional ingredients). The results of the analysis of the water content of potato crackers was $4.66 \%$, the breaking power was $14.90 \mathrm{~N}$ and the developing power was $83.2 \%$. The basic cost of making potato crackers is the third (three) formulation of 2,819.60 (IDR) per 100 grams.

Keywords: Granola Variety Potato, Tapioca Flour, Potato Crackers

\section{PENDAHULUAN}

Bromo memiliki keindahan pegunungan yang sangat cantik sebagai daya tarik akan keindahan alamnya. Sebagai tempat tujuan pariwisata, wisata gunung Bromo belum memiliki kuliner dan cinderamata yang khas dari daerah kawasan Taman Nasional Bromo Tengger Semeru. Adanya potensi komoditas unggulan kawasan Bromo untuk dikembangkan sebagai 
kuliner adalah sayuran kentang. Menurut Samadi (2007), kentang merupakan jenis tanaman hortikultura yang memanfaatkan umbinya untuk dikonsumsi. Jenis kentang yang banyak biasa ditanam di pegunungan Bromo adalah jenis varietas kentang granola. Kentang granola adalah salah satu varietas yang unggul dan digemari oleh konsumen (Rukmana, 2002). Varietas ini memiliki umur panen normal yaitu 90 hari, memiliki warna danging kuning, dan tahan terhadap hama penyakit yang umumnya dialami oleh tumbuhan kentang. Agar bernilai ekonomis dan mampu dijadikan makanan khas wisata Bromo, salah satu bentuk olahan yang cocok untuk umbi kentang yaitu diolah menjadi kerupuk kentang. Kentang juga banyak mengadung karbohidrat, protein, kalium, vitamin C, dan protein (Setiadi, 2009). Kentang memiliki kandungan pati yang cukup tinggi sehingga berpotensi diolah menjadi produk-produk yang memiliki kandungan karbohidrat tinggi diantaranya adalah keripik kentang, kerupuk kentang, bubur kentang, kentang goreng dan produk olahan lain yang tinggi karbohidrat.

Kentang dengan varietas Granola yang banyak ditanam dikawasan Taman Nasional Bromo Tengger Semeru mengandung kadar air yang sangat banyak dibanding varietas kentang lainnya. Kentang Granola mengandung kadar air sekitar 83.48\%. Menurut Asgar (2013) dalam penelitiannya, kentang dengan varietas Granola mengadung kadar air $82.30 \%$, kadar pati $6.67 \%$, dan kadar gula reduksi $0.12 \%$. Jika kentang varietas Granola digunakan sebagai olahan keripik maka yang dihasilkan warna keripik kurang menarik (kecoklatan) dan memiliki tekstur yang kurang renyah. Kerupuk merupakan makanan yang banyak disukai oleh masyarakat baik sebagai cemilan atau lauk pauk. Kerupuk umumnya dibuat dengan menggunakan tambahan bahan tepung tapioka sebagai sumber pati. Kerupuk mempunyai bentuk, warna, ukuran, aroma, dan jenis yang beragam (Suprapti, 2005). Perbedaan tersebut disebabkan oleh penggunaan bahan baku yang berbeda, jenis alat yang dipakai, bahan tambahan yang digunakan, maupun cara pengolahannya. Salah satu karakteristik yang paling menonjol pada konsumsi kerupuk adalah kerenyahan dan bentuk pengembangannya. Kerupuk dengan tekstur renyah akan mempunyai sifat padat dan mudah patah serta menghasilkan suara saat dipecahkan. Mengacu hal tersebut, perlu dibuat formulasi dan teknik pengolahan kerupuk yang tepat untuk menghasilkan kerupuk yang renyah dan diterima oleh masyarakat.

Berdasarkan permasalahan tersebut, maka perlu adanya ekplorasi tentang komoditas hasil perkebunan disekitar wilayah kawasan Taman Nasional Bromo Tengger Semeru dan upaya membuat formulasi kerupuk kentang yang sesuai dengan karakteristik kentang granola sebangai upaya menjadikan camilan kuliner kerupuk kentang sebagai kerupuk khas Tengger Bromo.

\section{METODE PENELITIAN}

\section{Bahan}

Bahan yang digunakan dalam pembuatan kerupuk kentang yaitu tepung tapioka, kentang granola, bawang, garam, minyak goreng, tablet kjedhal, $\mathrm{H}_{2} \mathrm{SO}_{4}$, aquades, $\mathrm{K}_{2} \mathrm{~S} 4 \%$, $\mathrm{NaOH} 45 \%, \mathrm{HCl}$, dan indikator metil red.

\section{Alat}

Alat yang digunakan dalam pembuatan kerupuk kentang yaitu timbangan digital, baskom, pisau, mortar, pencetak kerupuk, kompor, panci, oven, cawan, tanur, desikator, timbangan, lempeng Zn, labu kjedhal, labu ukur, oven, desikator, kertas saring, timbel, alat ekstraksi sokhlet, dan hot plate, stopwatch, dan desikator, penggaris, dan tensile strength.

\section{Metode}

Formulasi bahan pada penelitian ini dilakukan dengan menggunakan linear programming dengan fungsi tujuan ialah meminimalkan biaya pembuatan kerupuk kentang. Sedangkan rancangan yang digunakan pada penelitian ini ialah Rancangan Acak Lengkap (RAL) yang terdiri dari 3 perlakuan dan dilakukan 3 kali ulangan. Perbandingan komposisi bahan pada formulasi diperoleh dari hasil linear programming yaitu formulasi ke-1 (Kentang 
$50 \%$ : Tapioka $45 \%$ : 5\% bahan tambahan), formulasi ke-2 (Kentang 60\% : Tapioka 35\% : 5\% bahan tambahan), dan formulasi ke-3 (Kentang 65\%: Tapioka 30\%: 5\% bahan tambahan). Analisis data menggunakan software SPSS versi 16. Data yang dihasilkan dari uji kadar air, daya patah, dan daya kembang diuji menggunakan analisis sidik ragam (ANOVA) pada tingkat $\alpha=0.05$ untuk mengetauhi ada tidaknya perbedaan pada formulasi. Jika terdapat perbedaan yang nyata pada formulasi maka dilakukan uji Duncan Multiple Range Test (DMRT). Analisis nilai dari semua perlakuan dari uji organoleptik menggunakan uji Friedman. Sedangkan penentuan formulasi terbaik berdasarkan analisis organoleptik (rasa, aroma, tekstur, warna, dan penampakan) menggunakan metode De Garmo et al. (1984).

\section{Tahapan Penelitian}

Tahapan proses pembuatan kerupuk kentang diawali dengan mencuci kentang dengan air mengalir dan dilanjutkan dengan proses pengukusan selama 30 menit. Tahap selanjutnya yaitu mengupas kulit kentang dan menghaluskan dengan menggunakan mortal. Setelah kentang dihaluskan, campur dengan tepung tapioka dan selanjutnya ditambahkan dengan bumbu dan repah-rempah sambil diuleni. Perbandingan komposisi kentang dan tapioka yang digunakan pada formulasi ini dibatasi dengan formulasi ke-1 (Kentang 50\%: Tapioka 45\% : 5\% bahan tambahan), formulasi ke-2 (Kentang 60\% : Tapioka 35\%: $5 \%$ bahan tambahan), dan formulasi ke-3 (Kentang 65\% : Tapioka 30\% : 5\% bahan tambahan). Adonan kerupuk yang sudah diuleni dicetak dan dikukus selama 30 menit. Selanjutnya proses pengeringan terhadap kerupuk kentang dan dilanjutkan pada proses penggorengan. Proses Pembuatan kerupuk kentang dapat dilihat pada Gambar 1.

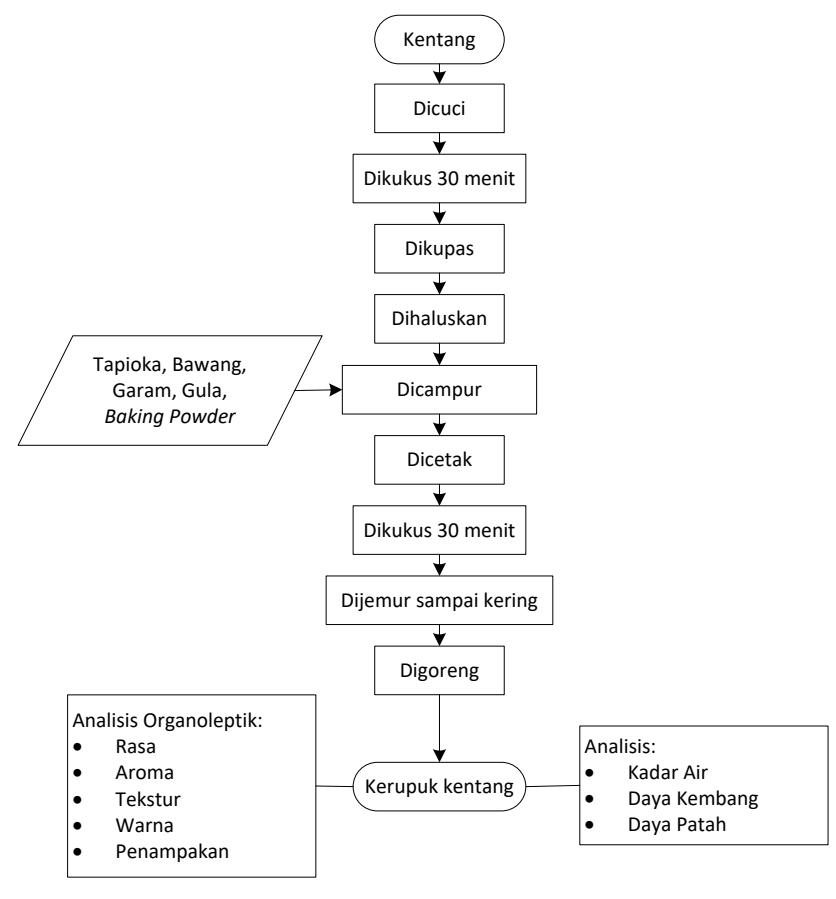

Gambar 1. Proses Pembuatan Kerupuk Kentang

HASIL DAN PEMBAHASAN

\section{Analisis Bahan Baku}

Analisis bahan baku pada penelitian ini meliputi analisis kadar air, kadar protein, dan total karbohidrat. Analisis bahan baku ini bertujuan untuk mengetahui karakteristik kimia bahan baku kerupuk kentang. Analisis bahan baku tersaji pada Tabel 1. 
Tabel 1. Hasil Analisis Bahan Baku

\begin{tabular}{lcc}
\hline \multirow{2}{*}{ Parameter } & \multicolumn{2}{c}{ Hasil Analisis } \\
\cline { 2 - 3 } & Kentang & Tapioka \\
\hline Kadar Air (\%) & 83.26 & 11.56 \\
Kadar Protein (\%) & 2.54 & 0.11 \\
Total Karbohidrat (\%) & 13.15 & 87.86 \\
\hline
\end{tabular}

Hasil analisis kadar air tepung tapioka (11.56\%) lebih tinggi dibanding dengan hasil pustaka Samadi (2007) sebesar (9\%). Perbedaan ini disebabkan pada pembuatan tepung tapioka saat proses stabilisasi yang menggunakan panas meliputi pengukusan dan pengeringan. Menurut Adi dkk (2013), pengeringan tepung tapioka dengan cara konvensional menggunakan sinar matahari mengakibatkan ketidakseragaman kadar air yang terdapat pada produk. Tepung tapioka yang baik sesuai dengan SNI memiliki kadar air maksimal 15\%.

Kadar protein hasil analisis tepung tapioka $(0.11 \%)$ lebih rendah dibandingkan dengan hasil pustaka Samadi (2007) sebesar (1.10\%), hal ini dapat disebabkan oleh beberapa faktor pada proses pengeringan. Menurut Sundari (2015), semakin tinggi suhu dan semakin lama pengolahan pada proses pemanasan maka akan mengakibatkan kadar protein pada bahan pangan semakin menurun. Protein pada pangan akan terdenaturasi apabila dipanaskan pada suhu $60-90^{\circ} \mathrm{C}$ sekitar selama 1 jam (Sugiran, 2007).

\section{Hasil formulasi dengan metode linear programming \\ 2.1 Variabel keputusan}

Ada empat variabel keputusan yang hendak dicari nilainya. Jumlah variabel tersebut sesuai dengan jumlah bahan yang ingin diformulasikan. Variabel keputusan tersebut ditetapkan sebagai berikut :

$\mathrm{X}_{1}=$ Kentang

$\mathrm{X}_{2}=$ Tapioka

$\mathrm{X}_{3}=$ Bawang

$\mathrm{X}_{4}=$ Garam

\section{Fungsi Tujuan}

Tujuan dari formulasi kerupuk kentang ini yaitu meminimumkan biaya. Untuk menetapkan fungsi tujuan ini, perlu diketahui harga dari masing-masing bahan yang akan diformulasikan. Dalam penetapan harga bahan-bahan tersebut, tentunya berbeda di setiap tempat atau pasar. Oleh karena itu, harga ditetapkan berdasarkan harga pembelian bahanbahan tersebut khususnya untuk kentang, bawang putih, tepung tapioka dan garam.

Tabel 2.1. Daftar harga bahan baku per 100 gram

\begin{tabular}{lc}
\hline \multicolumn{1}{c}{ Bahan baku } & $\begin{array}{c}\text { Harga per } \mathbf{1 0 0} \\
\text { gram (Rp) }\end{array}$ \\
\hline Kentang & 1.000 \\
Tepung tapioca & 550 \\
Bawang putih & 100 \\
Garam & 80 \\
\hline
\end{tabular}

Harga-harga yang ada pada Tabel 2.1 dijadikan sebagai koefisien variabel keputusan pada fungsi tujuan. Fungsi tujuan tersebut dapat dirumuskan :

$$
Z=1000 X 1+550 X 2+100 X 3+80 X 4
$$

\section{Sistem Kendala}

Dalam memformulasikan kerupuk kentang ini, ada tiga nutrisi yang ingin diseimbangkan yakni karbohidrat dan protein. Ketiga nutrisi tersebut diperoleh dari empat bahan yang telah diukur 
kandungan karbohidrat dan protein seperti yang tercantum dalam Tabel 1. Aktivitas yang ingin dicapai pada sistem kendala, yaitu berupa kebutuhan karbohidrat dan protein secara gizi dan juga jumlah penambahan kentang, tepung tapioka, garam dan bawang untuk menghasilkan kerupuk yang sesuai dengan standar kerupuk.

Kendala Formulasi ke-1:

Kentang: $X_{1} \geq 50 \%$

Tapioka: $X_{2} \leq 45 \%$

Bawang: $X_{3} \leq 3 \%$

Garam: $X_{4} \leq 2 \%$

Protein: $2,54 X_{1}+0,11 X_{2}+6,2 X_{3}+0 X_{4} \leq 16,17 \%$

Karbohidrat: $13,15 X_{1}+87,86 X_{2}+30,8 X_{3}+0 X_{4} \leq 80 \%$

Kendala Formulasi ke-2:

Kentang: $X_{1} \geq 60 \%$

Tapioka: $X_{2} \leq 35 \%$

Bawang: $X_{3} \leq 3 \%$

Garam: $X_{4} \leq 2 \%$

Protein: $2,54 \mathrm{X}_{1}+0,11 \mathrm{X}_{2}+6,2 \mathrm{X}_{3}+0 \mathrm{X}_{4} \leq 16,17 \%$

Karbohidrat: $13,15 X_{1}+87,86 X_{2}+30,8 X_{3}+0 X_{4} \leq 80 \%$

Kendala Formulasi ke-3:

Kentang: $X_{1} \geq 65 \%$

Tapioka: $X_{2} \leq 30 \%$

Bawang: $X_{3} \leq 3 \%$

Garam: $X_{4} \leq 2 \%$

Protein: $2,54 X_{1}+0,11 X_{2}+6,2 X_{3}+0 X_{4} \leq 16,17 \%$

Karbohidrat: $13,15 X_{1}+87,86 X_{2}+30,8 X_{3}+0 X_{4} \leq 80 \%$

\subsection{Hasil optimasi}

Permasalahan yang telah dioptimasikan menggunakan metode matematika, diperoleh 3 formulasi yang disajikan pada tabel 2.1, tabel 2.2 dan tabel 2.3. Berdasarkan pada tabel hasil optimasi didapatkan biaya produksi formulasi I paling rendah dibandingkan dengan formulasi II dan III. Semakin banyak kentang yang digunakan maka biaya produksi menjadi lebih tinggi.

Tabel 2.1 Komposisi Formulasi I

\begin{tabular}{ccccccc}
\hline Bahan Baku & Kentang & Tapioka & Bawang & Garam & Total & Kebutuhan (\%) \\
\hline $\begin{array}{c}\text { Komposisi Bahan } \\
\text { Baku (\%) }\end{array}$ & 50 & 45 & 3 & 2 & 100 & 100 \\
\hline Parameter & & & & & & \\
\hline Protein & 2,54 & 0,11 & 6,2 & 0 & 1,75 & $5,53-16,17$ \\
\hline Karbohidrat & 13,15 & 87,86 & 30,8 & 0 & 38,57 & $50-80$ \\
\hline Harga / 100 gram & 1000 & 550 & 100 & 80 & $\mathbf{7 5 2 , 1}$ & \\
\hline
\end{tabular}


Tabel 2.1 Komposisi Formulasi II

\begin{tabular}{ccccccc}
\hline Bahan Baku & Kentang & Tapioka & Bawang & Garam & Total & Kebutuhan (\%) \\
\hline $\begin{array}{c}\text { Komposisi Bahan Baku } \\
(\%)\end{array}$ & 60 & 35 & 3 & 2 & 100 & 100 \\
\hline Parameter & & & & & & \\
\hline Protein & 2,54 & 0,11 & 6,2 & 0 & 1,75 & $5,53-16,17$ \\
\hline Karbohidrat & 13,15 & 87,86 & 30,8 & 0 & 38,57 & $50-80$ \\
\hline Harga / 100 gram & 1000 & 550 & 100 & 80 & 797,1 & \\
\hline
\end{tabular}

Tabel 2.2 Komposisi Formulasi III

\begin{tabular}{ccccccc}
\hline Bahan Baku & Kentang & Tapioka & Bawang & Garam & Total & Kebutuhan (\%) \\
\hline $\begin{array}{c}\text { Komposisi } \\
\text { Bahan } \\
\text { Baku (\%) }\end{array}$ & 65 & 30 & 3 & 2 & 100 & 100 \\
\hline Parameter & 2,54 & 0,11 & 6,2 & 0 & 1,75 & $5,53-16,17$ \\
\hline Protein & 87,86 & 30,8 & 0 & 38,57 & $50-80$ \\
\hline Karbohidrat & 13,15 & 550 & 100 & 80 & $\mathbf{8 1 9 , 6}$ & \\
\hline $\begin{array}{c}\text { Harga / 100 } \\
\text { gram }\end{array}$ & 1000 & & & & \\
\hline
\end{tabular}

\section{Uji Kimia Kerupuk Kentang \\ Kadar Air Kerupuk}

Uji kimia kerupuk kentang pada penelitian ini ialah kadar air. Uji kimia kerupuk kentang tersaji pada Tabel 3.

Tabel 3. Hasil Analisis Kadar Air

Perlakuan

Formulasi I (Kentang 50\% : Tapioka 45\% : Bahan Tambahan

$5 \%)$

Formulasi II (Kentang 60\% : Tapioka 35\% : Bahan Tambahan

$5 \%)$

Formulasi III (Kentang 65\% : Tapioka 30\% : Bahan

Tambahan 5\%)

Tabel 2 menunjukkan bahwa rerata kadar air kerupuk kentang berkisar antara $4.66 \%$ - 5.56\%. Kadar air pada kerupuk kentang tertinggi terdapat pada formulasi II dengan nilai $5.56 \%$ (formulasi dengan penggunaan bahan baku kentang 60\%, tepung tapioka 35\% dengan penggunaan bahan tambahan sebesar $5 \%$ ). Kadar air terendah pada formulasi III dengan nilai $4.66 \%$ (formulasi dengan penggunaan bahan baku kentang $65 \%$, tepung tapioka $30 \%$ dengan penggunaan bahan tambahan sebesar $5 \%$ ). Berdasarkan hasil analisis ragam kadar air menunjukkan bahwa perlakuan proporsi kentang dan tepung tapioka pada berbagai formulasi tidak berbeda nyata (taraf $\alpha=0.05$ ).

Menurut Tabita dalam Nurainy (2015), dalam suatu bahan yang mengandung beberapa perbedaan jenis maupun jumlah pati akan menyebabkan perbedaan nilai kapasitas absorb air dalam suatu bahan. Semakin banyak pati dalam bahan makanan, maka kapasitas dalam absorbs air semakin besar. Semakain banyak penambahan tepung tapioka, semakin tinggi kadar amilopektin yang terdapat pada suatu bahan. Tingginya kadar amilopektin akan terjadi penyerapan air yang semakin tinggi karena sifat amilopektin yang mudah menyerap air dan menahan air pada saat pengukusan (Thomas and Atwell, 1997). Syarat mutu kerupuk menurut SNI kadar air kerupuk maksimum sebesar 12\% (Badan Standarisasi Nasional, 1991). 


\section{Uji Fisik Kerupuk Kentang}

\subsection{Daya Patah Kerupuk}

Uji fisik kerupuk kentang pada penelitian ini meliputi daya payah dan daya kembang. Uji fisik kerupuk kentang tersaji pada Tabel 4.1.

Tabel 4.1 Hasil Analisis Daya Patah

\begin{tabular}{|c|c|}
\hline Perlakuan & Rerata Daya Patah (N) \\
\hline $\begin{array}{l}\text { Formulasi I (Kentang 50\% : Tapioka 45\% : Bahan Tambahan } \\
5 \% \text { ) }\end{array}$ & $21.07^{a}$ \\
\hline $\begin{array}{l}\text { Formulasi II (Kentang 60\% : Tapioka 35\% : Bahan Tambahan } \\
5 \% \text { ) }\end{array}$ & $19.30^{a}$ \\
\hline $\begin{array}{l}\text { Formulasi III (Kentang 65\% : Tapioka 30\% : Bahan } \\
\text { Tambahan 5\%) }\end{array}$ & $14.90^{\mathrm{a}}$ \\
\hline
\end{tabular}

Tabel 4 menunjukkan bahwa rerata daya patah kerupuk kentang berkisar antara 14.90 $\mathrm{N}-21.07 \mathrm{~N}$. Daya patah pada kerupuk kentang tertinggi terdapat pada formulasi I dengan nilai $21.07 \mathrm{~N}$ (formulasi dengan penggunaan bahan baku kentang 50\%, tepung tapioka $45 \%$ dengan penggunaan bahan tambahan sebesar $5 \%$ ). Daya patah terendah pada formulasi III dengan nilai $14.90 \mathrm{~N}$ (formulasi dengan penggunaan bahan baku kentang 65\%, tepung tapioka $30 \%$ dengan penggunaan bahan tambahan sebesar $5 \%$ ). Berdasarkan hasil analisis ragam daya patah menunjukkan bahwa perlakuan proporsi kentang dan tepung tapioka pada berbagai formulasi tidak berbeda nyata (taraf $\alpha=0.05$ ).

Daya yang dibutuhkan kerupuk untuk dipatahkan memiliki korelasi dengan nilai pengembangan dari kerupuk. Semakin rendah tepung tapioka yang ditambahkan pada adonan kerupuk, maka pengembangan kerupuk juga semakin rendah. Hal ini terjadi karena menurunnya komponen pati, dimana pada kerupuk pati merupakan ingredient utama yang dapat membentuk body pada kerupuk. Kandungan pati ketang lebih rendah dibandingkan dengan kandungan pati pada tepung tapioka. Amilopektin merupakan komponen dari pati yang paling berperan dalam pengembangannya, dimana sifat amilopektin dapat membentuk long texture sangat dibutuhkan pada adonan kerupuk. Ketika penggunaan tepung tapioka dalam jumlah yang kurang memadai menyebabkan rendahnya pati sehingga gel yang terbentuk semakin lemah dan matrik yang terbentuk kurang kuat (Subekti, 1998). Menurut Dewa (2008) faktor-faktor yang mempengaruhi besarnya daya patah pada suatu produk antara lain: (1) kadar air, dimana semakin banyak air maka rongga yang terbentuk akan semakin banyak dan mengakibatkan kerupuk mudah patah (daya patah tinggi). (2) ketebalan produk, semakin tinggi ketebalan kerupuk maka daya patah kerupuk juga menjadi rendah. (3) kadar protein.

\subsection{Daya Kembang Kerupuk}

Uji fisik kerupuk kentang pada penelitian ini meliputi daya payah dan daya kembang. Uji fisik kerupuk kentang tersaji pada Tabel 4.2.

Tabel 4.2 Hasil Analisis Daya Patah

Perlakuan Rerata Daya Kembang

$(\mathrm{N})$

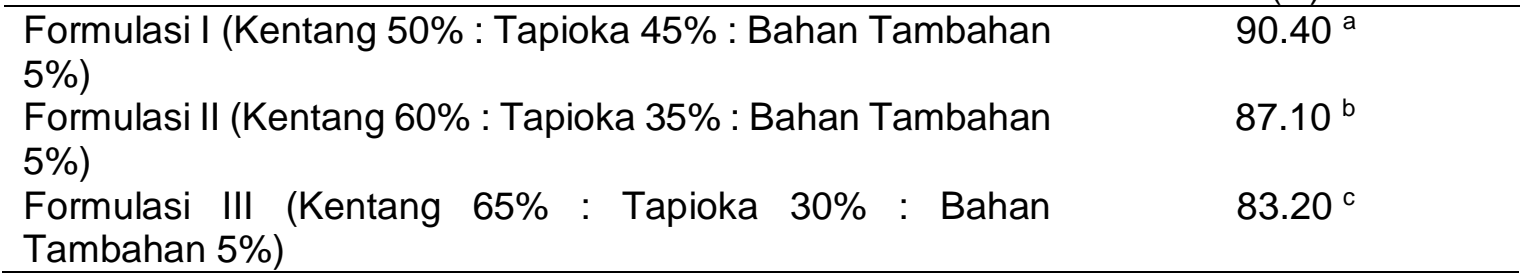

Tabel 4.2 menunjukkan bahwa rerata daya kembang kerupuk kentang berkisar antara 
$83.2 \%-90.4 \%$. Daya kembang pada kerupuk kentang tertinggi terdapat pada formulasi I dengan nilai $90.4 \%$ (formulasi dengan penggunaan bahan baku kentang $50 \%$, tepung tapioka $45 \%$ dengan penggunaan bahan tambahan sebesar 5\%). Daya patah terendah pada formulasi III dengan nilai $83.2 \%$ (formulasi dengan penggunaan bahan baku kentang $65 \%$, tepung tapioka $30 \%$ dengan penggunaan bahan tambahan sebesar $5 \%$ ). Berdasarkan hasil analisis ragam daya kembang menunjukkan bahwa perlakuan proporsi kentang dan tepung tapioka pada berbagai formulasi berbeda nyata (taraf $\alpha=0.05$ ).

Daya kembang yang optimal menunjukkan pematangan pada seluruh bagian kerupuk. Menurut Nurainy (2015), tidak optimalnya proses pengembangan kerupuk diakibatkan oleh adanya kandungan bahan lain selain pati seperti protein dan serat yang dapat mempengaruhi proses gelatinisasi pati sehingga menurukan derajat pengembangan pada proses penggorengan. Protein biasa terikat sebagai matriks dengan butiran pati. Selain kandungan protein faktor yang mempengaruhi pengembangan kerupuk adalah kadar air, kadar air kerupuk mentah akan sangat mempengaruhi kemekaran kerupuk saat digoreng (Purnomo dalam Zulisyanto, 2016).

\section{Uji Organoleptik}

Hasil nilai penerimaan konsumen terhadap produk kerupuk kentang dapat diketahui dengan melakukan uji organoleptik yang meliputi parameter uji rasa, aroma, tekstur, warna, dan penampakan. Uji organoleptik ini menggunakan bantuan 30 panelis tidak terlatih dengan menggunakan uji hedonic scale scoring 7 skala untuk mewakili tingkat kesukaan. Hasil organoleptik dapat dilihat pada Gambar 2.

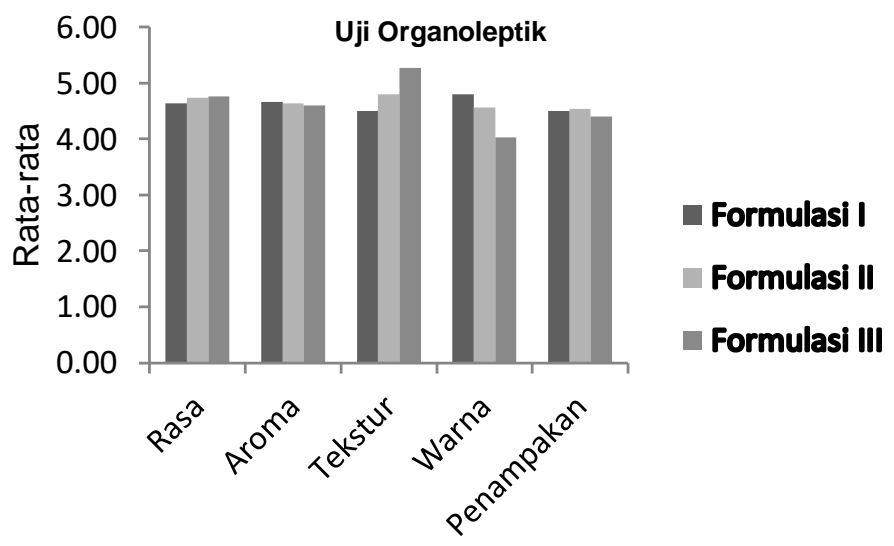

Gambar 2. Hasil Organoleptik Kerupuk Kentang

\subsection{Rasa}

Analisis nilai organoleptik rasa menggunakan uji Friedman dapat diketahui bahwaformulasi kerupuk kentang memberikan hasil yang tidak berbeda nyata (taraf $\alpha=0.05$ ). Rasa yang muncul pada makanan kerupuk dipengaruhi oleh komposisi bumbu yang diberikan pada proses pembuatan kerupuk. Hasil rasa yang dihasilkan pada formulasi kerupuk kentang ini adalah agak asin. Menurut Hudayan dan Darajat dalam Rosiani (2015), menjelaskan dalam industri pangan fungsi garam ialah sebagai bahan pemberi rasa. Penggunaan garam dalam formulasi kerupuk kentang diberikan tidak terlalu banyak, hal ini dikarenakan jika pemberian garam terlalu banyak akan mempengaruhi cita rasa produk. Makanan akan memiliki rasa bila mengandung garam minimal $0.3 \%$, kurang dari itu maka makan akan terasa hambar (Purawisastra dan Yuniati, 2010).

\subsection{Aroma}

Analisis nilai organoleptik aroma menggunakan uji Friedman dapat diketauhi bahwa formulasi kerupuk kentang memberikan hasil yang tidak berbeda nyata (taraf $\alpha=0.05$ ). 
Penyebab timbulnya aroma pada kerupuk kentang diduga karena semakin banyak persentase penambahan kentang yang mengakibatkan semakin tajamnya aroma gosong yang dihasilkan oleh kerupuk kentang. Hal ini dikarenakan adanya kandungan gula reduksi yang ada dalam kentang. Menurut Asgar (2013) bahwa kandungan gula yang terlalu tinggi pada umbi kentang (immature) yang menyebabkan rasa manis pada umbi kentang. Gula reduksi semakin meningkat dengan bertambahnya proporsi kentang sehingga akan menghasilkan warna yang kecoklatan dan aroma gosong. Selama proses pemanggangan atau penggorengan terjadi reaksi karamelisasi gula yang mengakibatkan pencoklatan pada permukaan produk dan aroma yang kurang sedap (Winarno, 2002).

\subsection{Tekstur}

Analisis nilai organoleptik rasa menggunakan uji Friedman dapat diketauhi bahwa formulasi kerupuk kentang memberikan hasil yang berbeda nyata (taraf $\alpha=0.05$ ). Adanya perbedaan tekstur dari formulasi kerupuk kentang diduga karena persentase tepung tapioka yang digunakan berbeda. Hal ini dikarenakan semakin tinggi proporsi tepung tapioka maka daya patah kerupuk yang dihasilkan semakin besar. Menurut Rosiani (2015) fungsi dari amilopektin pada pati ialah pemberi sifat renyah pada kerupuk. Kerenyahan suatu produk dapat dilihat dari daya patah produk itu sendiri, semakin rendah daya patah yang dimiliki produk maka semakin renyah produk tersebut, begitu pula sebaliknya (Setyowati, 2001).

\subsection{Warna}

Analisis nilai organoleptik warna menggunakan uji Friedman dapat diketauhi bahwa formulasi kerupuk kentang memberikan hasil yang tidak berbeda nyata (taraf $\alpha=0.05$ ). Menurut Winarno dalam Rosiani (2015) menjelaskan bahwa warna dalam bahan bisa berasal dari pigmen alami bahan itu sendiri, reaksi maillard, reaksi karamelisasi, reaksi senyawa organik dengan udara, dan penambahan warna alami atau sintetik. Proses pencoklatan pada kerupuk kentang diakibatkan oleh adanya gula reduksi yang berasal dari kentang. Proses pemanasan dapat meyebabkan terjadinya reaksi karamelisasi antara gula yang menghasilkan pembentukan warna coklat (Winarno, 2002).

\subsection{Penampakan}

Berdasarkan analisis nilai organoleptik penampakan menggunakan uji Friedman dapat diketahui bahwa formulasi kerupuk kentang memberikan hasil yang tidak berbeda nyata (taraf $\alpha=0.05$ ). Adanya suatu perbedaan penampakan dari formulasi kerupuk kentang diduga karena persentase tepung tapioka yang digunakan berbeda. Hal ini berkaitan dengan daya kembang, semakin tinggi proporsi tepung tapioka dan semain rendah proporsi kentang yang digunakan maka kerupuk yang dihasilkan semakin mengembang dan disertai dengan adanya rongga-rongga yang besar. Menurut Pangloli (2000) karakteristik kerupuk yang baik adalah kerupuk dengan volume pengembangan yang besar saat proses penggorengan.

\section{Pemilihan Perlakuan Terbaik}

Hasil Nilai Produk (NP) pemilihan perlakuan terbaik kerupuk kentang berdasarkan uji fisik dan organoleptik tersaji pada Tabel 6.

Tabel 6. Nilai Produk (NP) Pemilihan Perlakuan Terbaik

\begin{tabular}{lc}
\hline Formulasi & NP \\
\hline Formulasi I (Kentang 50\% : Tapioka 45\% : Bahan Tambahan 5\%) & 0.41 \\
Formulasi II (Kentang 60\% : Tapioka 35\%: Bahan Tambahan 5\%) & 0.53 \\
Formulasi III (Kentang 65\% : Tapioka 30\%: Bahan Tambahan 5\%) & $0.76{ }^{\star}$ \\
\hline
\end{tabular}

Keterangan : ${ }^{*}=$ Nilai Tertinggi Perlakuan Terbaik

Berdasarkan Tabel 5 produk formulasi III memiliki nilai produk tertinggi yaitu sebesar 0.76 dengan perlakuan komposisi bahan baku 65\% kentang, 30\% tepung tapioka, dan bahan tambahan sebesar $5 \%$. Nilai produk terendah pada formulasi I yaitu sebesar 0.41 dengan 
perlakuan komposisi bahan baku 50\% kentang, 50\% tepung tapioka, bahan tambahan sebesar $5 \%$.

Adapun perlakuan terbaik pada formulasi III memiliki tingkat kesukaan panelis terhadap rasa sebesar 4.77 yang artinya netral, kesukaan panelis terhadap aroma sebesar 4.67 yang artinya netral, kesukaan panelis terhadap tekstur sebesar 5.27 yang artinya agak menyukai kerupuk kentang, kesukaan panelis terhadap warna sebesar 4.80 yang artinya netral, dan kesukaan panelis terhadap penampakan sebesar 4.53 yang artinya netral.

\section{Analisis Kimia Kerupuk Kentang Perlakuan Terbaik}

Kerupuk kentang terbaik dipilih dari nilai tertinggi perlakuan dari ketiga formulasi kerupuk kentang. Perlakuan terbaik didapat dengan nilai tertinggi sebesar 0.75 yaitu terdapat pada formulasi III (kentang 65\%, tapioka 30\%, bahan tambahan 5\%). Analisis kandungan kimia kerupuk kentang tersaji pada Tabel 7.

Tabel 7. Kandungan Kimia Kerupuk Perlakuan Terbaik

\begin{tabular}{lc}
\hline Parameter & Hasil Analisis \\
\hline Protein (\%) & 1.83 \\
Kadar Air (\%) & 4.03 \\
Karbohidrat (\%) & 68.11 \\
\hline
\end{tabular}

Berdasarkan Tabel 7 kerupuk kentang perlakuan terbaik memiliki kandungan protein sebesar $1.83 \%$. Rendahnya kandungan protein pada kerupuk tergantung pada bahan baku apa yang digunakan, kerupuk dengan kandungan protein yang tinggi pada proses pembuatannya biasanya ditambahkan dengan sumber protein hewani seperti daging ikan atau udang (Adawya dan Findya, 2012). Menurut Huda et.al (2010), kandungan protein kerupuk komersial diantara $5.53 \%$ sampai $16.17 \%$.

Kerupuk dengan kandungan protein yang besar akan mempengaruhi warna dari kerupuk. Karena pada proses penggorengan akan terjadi reaksi Maillard. Sedangkan kandungan karbohidrat kerupuk kentang perlakuan terbaik sebesar $68.11 \%$. Menurut Huda et.al (2010), kandungan karbohidrat kerupuk komersial diantara 50\% sampai $80 \%$. Penyebab tingginya kadar karbohidrat karena jenis bahan baku yang digunakan, khususnya tepung yang digunakan mengandung sumber karbohidrat tinggi. Tepung tapioka mengandung kadar karbohidrat sebesar 84.2\% (Purwanita, 2013).

\section{Hasil Analisis Biaya Pokok}

Penentuan harga pokok produksi kerupuk kentang merujuk pada metode Harga Pokok Variabel (Variable Costing). Metode Harga Pokok Variabel (Variable Costing) merupakan metode penentuan harga pokok produksi yang hanya memperhitungkan biaya produksi. Dimana biaya produksi bersifat variabel dan memberikan pengaruh terhadap harga pokok produksi. Harga pokok produksi tersusun atas biaya bahan baku, biaya tenaga kerja, dan biaya overhead (Mulyadi, 2012). Biaya pokok pembuatan kerupuk kentang formulasi III (tiga) dengan pemakaian bahan baku kentang sebesar $65 \%$, tepung tapioka $30 \%$, dan bahan tambahan sebesar 5\% menghasilkan biaya awal dengan total Rp. 819,60 per 100 gram dan biaya overhead (energi) sebesar Rp. 2000,00 untuk sekali proses, sehingga total biaya yang dibutuhkan sebesar Rp. 2.819,60 per 100 gram.

\section{SIMPULAN}

Penggunaan proporsi kentang Granola dengan tepung tapioka memberikan pengaruh signifikan terhadap daya kembang. Semakin banyak tepung tapioka yang ditambahkan maka daya kembang semakin baik. Namun jika tepung tapioka yang digunakan sedikit maka daya kembang yang dihasilkan kurang baik. Kerupuk kentang dapat diterima secara organoleptik (rasa, aroma, tekstur, warna, penampakan) oleh panelis adalah perlakuan formulasi III yaitu dengan komposisi bahan baku tepung tapioka $30 \%$, kentang $65 \%$, dan bahan tambahan $5 \%$. 
Hasil perlakuan terbaik uji kadar air kerupuk kentang sebesar $4.66 \%$. Hasil uji fisik kerupuk kentang perlakuan terbaik memiliki daya patah sebesar $14.90 \mathrm{~N}$ dan daya kembang sebesar $83.2 \%$. Kerupuk kentang perlakuan terbaik memiliki kandungan protein sebesar $1.83 \%$ dan karbohidrat sebesar $68.11 \%$. Biaya pokok pembuatan kerupuk kentang 100 gram sebesar Rp. 2.819,60

\section{DAFTAR PUSTAKA}

Adawyah, R dan Findya, P. 2012. Pemberian Ekstrak Limbah Kepala Udang Sebagai Sumber Protein Pelengkap Unsur Gizi Pada Pengolahan Kerupuk. Journal Fish Scientiae. 2:3, $51-63$

Adi, R., N., Nafiah, A., Suherman, dan Ratnawati. 2013. Penggunaan Teknologi Pengeringan Unggun Terfluidisasi Untuk Meningkatkan efisiensi Pengeringan Tepung Tapioka. Jurnal Teknologi Kimia, Industri. 2:3, 37-42

Asgar, A. 2013. Kualitas Umbi Beberapa Klon Kentang (Solanum Tuberosum L.) Dataran Medium Untuk Keripik. Jurnal Berita Biologi. 12:1, 29-37

Badan Standarisasi Nasional. 1991. Standar Nasional Indonesia (SNI). SNI-01- 0272-1991. Mutu Kerupuk. Dewan Standarisasi Indonesia. Jakarta

De Garmo, E.P.W.G. Sullivan dan J.R. Canada. 1984. Engineering Economy The 7th Edition. Macmillan Publishing Comp., New York.

Dewa, I. Gede P. J. 2008. Karakteristik Biskuit Berserat Hasil Suplementasi Tepung Ampas Tahu Dan Tepung Ampas Kelapa. Skripsi. Jurusan Teknologi Hasil Pertanian Fakultas Teknologi Pertanian UB. Malang

Huda N. , Ang L. L., Chung X. Y. and Herpandi. 2010. Chemical Composition, Colour and Linear Expansion Properties of Malaysian Commercial Fish Cracker (Keropok). Asian Journal of Food and Agro-Industry 3:05, 473-482 ISSN 1906-3040.

Mulyadi. 2012. Akuntansi Biaya. Unit Penerbit dan Percetakan Sekolah Tinggi IImu Manajemen. YKPN. Yogyakarta.

Nurainy, F., Ribut, S., dan Dewe, W. 2015. Pengaruh Perbandingan Tepung Tapioka Dan Tepung Jamur Tiram Putih (Pleurotus Oestreatus) Terhadap Volume Pengembangan. Kadar Protein Dan Organoleptik Kerupuk. Jurnal Teknologi Industri, Hasil Pertanian. $20: 1,11-24$

Pangloli, P. Dan Hariyanto, B. 2000. Potensi Dan Pemanfaatan Sagu. Kanisius. Yogyakarta

Purawisastra, S. dan H. Yuniati. 2010. Kandungan Natrium Beberapa Jenis Sambal Kemasan serta Uji Tingkat Penerimaannya. Puslitbang Gajah Mada, Yogyakarta

Purwanita dan Ratna, S. 2013. Pembuatan Egg Roll Tepung Sukun (Artocarpus Altilis) dengan Penambahan Jumlah Tepung Tapioka yang Berbeda. Jurnal Penelitian. 3:1, $1-157$

Rosiani, N., Basito, Esti, W. 2015. Kajian Karakteristik Sensoris Fisik Dan Kimia Kerupuk Fortifikasi Daging Lidah Buaya (Aloe Vera) Dengan Metode Pemanggangan Menggunakan Microwave. Jurnal Teknologi Pertanian. 8:2, 84-98

Rukmana, R. H. 2002. Usaha Tani Kentang Sistem Mulsa Plastik. PT Kanisius. Yogyakarta

Samadi, B. 2007. Kentang dan Analisis Usaha Tani. Penerbit Kanisius. Yogyakarta

Setiadi. 2009. Budi Daya Kentang. Penebar Swadaya. Jakarta

Setyowati. 2001. Penggunaan $\mathrm{NaHCO}_{3}$ Terhadap Kualitas Kerupuk Biji Nangka. Skipsi. Universitas Brawijaya. Malang.

Subekti, E. I. 1998. Optimasi Perencanaan Produksi Industri Kerupuk Udang/lkan Di Perusahaan Kerupuk Indrasari. Indramayu.

Sugiran , G. 2007. Efek Pengolahan Terhadap Zat Gizi Pangan. Fakultas Pertanian Universitas Lampung. Lampung.

Sundari, D., Al,asyhuri, dan Astuti, L. 2015. Pengaruh Proses Pemasakan Terhadap Komposisi Zat Gizi Bahan Pangan Sumber Protein. Jurnal Media Litbangkes. 25:4, 235-242

Suprapti, L. 2005. Teknologi Pengolahan Pangan Tepung Tapioka dan Pemanfaatannya. PT 
Gramedia Pustaka: Jakarta.

Thomas, W., J. dan Arwell, W., A. 1997. Starch. Eagan Press Handbook Series St Paul Minnesota. USA

Winarno, F. G. 2002. Kimia Pangan dan gizi. PT. Gramedia Pustaka Utama. Jakarta

Zulistyanto, D., Putut H., dan Ulfah A. 2016. Pengaruh Lama Pengukusan Adonan Terhadap Kualitas Fisik Dan Kimia Kerupuk Ikan Lele Dumbo (Clarias gariepinus). Jurnal Pengolahan, Bioteknologi Hasil Perikanan. 5:4, 26-3 